\title{
Effect of carbonate chemistry manipulations on calcification, respiration, and excretion of a Mediterranean pteropod
}

S. Comeau ${ }^{1,2,3}$, J.-P. Gattuso ${ }^{1,2}$, R. Jeffree ${ }^{4,5}$, and F. Gazeau ${ }^{1,2}$

${ }^{1}$ CNRS-INSU, Laboratoire d'Océanographie de Villefranche, BP 28, 06234

Villefranche-sur-Mer Cedex, France

${ }^{2}$ Université Pierre et Marie Curie, Observatoire Océanologique de Villefranche, 06230

Villefranche-sur-Mer, France

${ }^{3}$ Present address: Department of Biology, California State University, 18111 Nordhoff Street, Northridge, CA 91330-8303, USA

${ }^{4}$ Marine Environmental Laboratories, International Atomic Energy Agency, 4 quai Antoine ${ }^{\text {er }}$ 98000 Monaco, Principality of Monaco

${ }^{5}$ Faculty of Science, University of Technology, Sydney, P.O. Box 123, Broadway NSW 2007, Australia
Effect of the carbonate chemistry on a pteropod

S. Comeau et al.

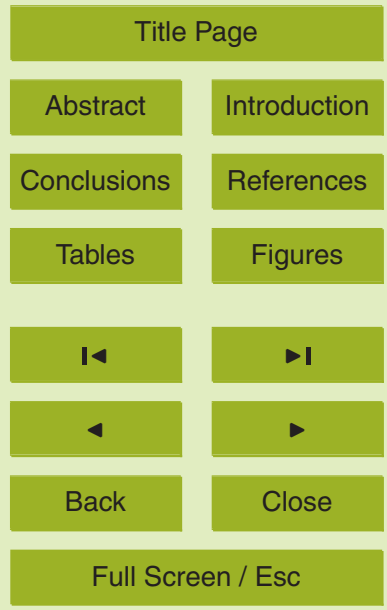

Printer-friendly Version

Interactive Discussion 
Received: 6 April 2012 - Accepted: 6 May 2012 - Published: 30 May 2012

Correspondence to: S. Comeau (steve.comeau @ csun.edu)

Published by Copernicus Publications on behalf of the European Geosciences Union.
BGD

9, 6169-6189, 2012

\section{Effect of the carbonate chemistry on a pteropod}

S. Comeau et al.

Title Page

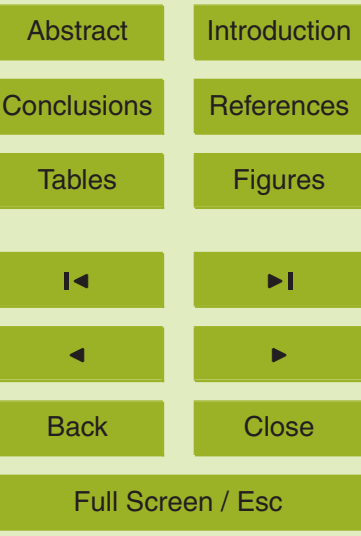

Printer-friendly Version

Interactive Discussion 


\section{Abstract}

Although shelled pteropods are expected to be particularly sensitive to ocean acidification, the few available studies have mostly focused on polar species and have not allowed determining which parameter of the carbonate system controls their cal5 cification. Specimens of the temperate Mediterranean species Creseis acicula were maintained under seven different conditions of the carbonate chemistry, obtained by manipulating $\mathrm{pH}$ and total alkalinity, with the goal to disentangle the effects of the $\mathrm{pH}$ and the saturation state with respect to aragonite $\left(\Omega_{\mathrm{a}}\right)$. Our results tend to show that respiration, excretion as well as rates of net and gross calcification were not directly affected by a decrease in $\mathrm{pH}$ but decreased significantly with a decrease in $\Omega_{\mathrm{a}}$. Due to the difficulties in maintaining pteropods in the laboratory and the important variability in their abundances in our study site, long-term acclimation as well as replication of the experiment was not possible. However, we strongly believe that these results represent an important step in the mechanistic understanding of the effect of ocean acidification on pteropods physiology.

\section{Introduction}

The oceans play a crucial role in the global carbon cycle and store about one quarter of the anthropogenic $\mathrm{CO}_{2}$ emissions since 1800 (Sabine et al., 2004). By limiting the accumulation of $\mathrm{CO}_{2}$ in the atmosphere, and therefore climate change, this ocean $\mathrm{CO}_{2}$ uptake has a beneficial environmental effect. However, when $\mathrm{CO}_{2}$ dissolves in seawater, it forms carbonic acid, and generates a decrease in $\mathrm{pH}$, in the concentration of carbonate ions $\left(\mathrm{CO}_{3}^{2-}\right)$ and its associated calcium carbonate saturation state $(\Omega)$. Since pre-industrial time, surface ocean $\mathrm{pH}$ has declined by 0.1 unit (Orr et al., 2005 ) and, according to model projections, a further decrease of 0.3-0.4 unit is anticipated for the end of the century (Orr, 2011). Most studies have shown a decrease in calcification rates with decreasing $\mathrm{pH}$ levels for organisms such as coccolithophorids
BGD

9, 6169-6189, 2012

\section{Effect of the carbonate chemistry on a pteropod}

S. Comeau et al.

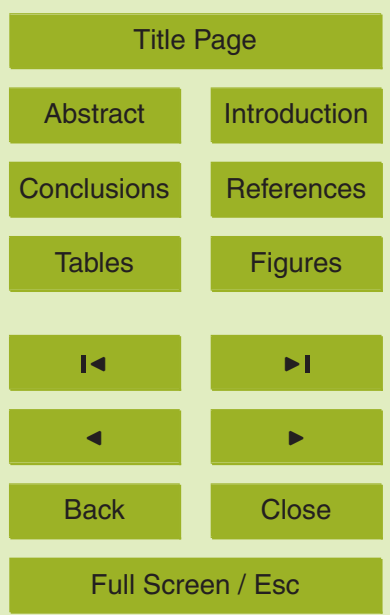

Printer-friendly Version

Interactive Discussion 
(e.g., Riebesell et al., 2000), commercial mollusks (e.g., Gazeau et al., 2007), corals and coralline algae (e.g., Langdon and Atkinson, 2005). However, some recent studies have also brought contradictory results such as no effect or even a positive effect of increasing $\mathrm{CO}_{2}$ on calcification (e.g., Iglesias-Rodrigez et al., 2008; Ries et al., 2009).

Pteropods are widely distributed holoplanktonic mollusks (Lalli and Gilmer, 1989) which play a fundamental role in pelagic ecosystems, being an important food source for various predators such as zooplankton, fishes and birds (e.g., Hunt et al., 2008). The thecosome or "shelled pteropod" species produce an external fragile calcium carbonate shell made of aragonite. They contribute to the majority of the aragonite flux 10 in the ocean that represents at least $12 \%$ of the total calcium carbonate flux (Berner and Honjo, 1981). Pteropods are particularly abundant at high latitudes, where aragonite undersaturation is expected in the coming decades (Steinacher et al., 2009), but are also important components of temperate and tropical ecosystems (Bé and Gilmer, 1977). Note that their importance in the Mediterranean pelagic food web is not well documented. The few studies dealing with the effect of ocean acidification on pteropods have focused on high latitudes species (Orr et al., 2005; Comeau et al., 2009, 2010b; Lischka et al., 2011), and have shown sign of shell dissolution and significant reductions in calcification rates under $\mathrm{pCO}_{2}$ levels projected for the end of the century.

Only two published studies have focused on the effect of ocean acidification on 20 temperate and tropical pteropods; one was restricted to the larval development of a Mediterranean species (Comeau et al., 2010a), and the second one was limited to the impact of ocean acidification on respiration and excretion rates of five tropical pteropod species (Maas et al., 2012). Moreover, it is, at present, unknown whether the observed effects of ocean acidification on pteropods are due to the variations of $\mathrm{pH}, \Omega$ 25 and/or another parameter of the carbonate system. There is a strong need, for mechanistic understanding as well as modelling, to perform experiments designed to disentangle the effects of the carbonate system parameters on pteropods, as it has been recently done on corals (Jury et al., 2010). Finally, in addition to calcification, there is also a great need to evaluate the effect of these perturbations on other important

\section{BGD}

$9,6169-6189,2012$

\section{Effect of the carbonate chemistry on a pteropod}

S. Comeau et al.

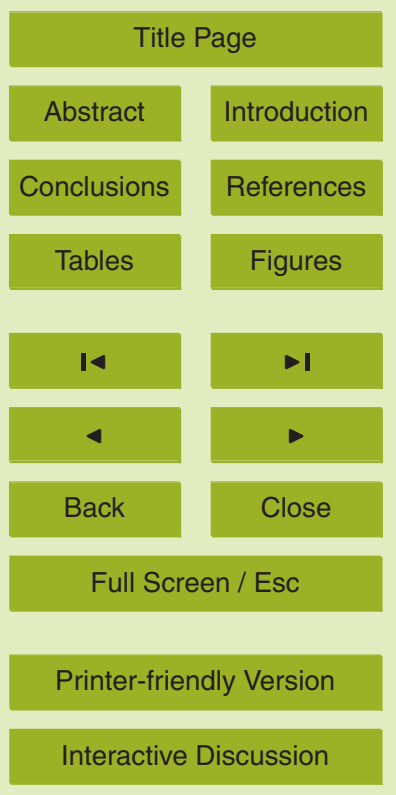


physiological processes such as respiration and excretion (e.g., Maas et al., 2012). Our study aims at providing indications on the effects of various levels of $\mathrm{pH}$ and $\Omega_{\mathrm{a}}$ on respiration, excretion and calcification rates of the Mediterranean thecosome pteropod Creseis acicula and to contribute to the understanding of pteropods physiological 5 response to carbonate chemistry changes.

\section{Materials and methods}

Creseis acicula specimens were sampled, using a plankton net, in the Bay of Villefranche-sur-Mer (NW Mediterranean Sea; $43^{\circ} 40^{\prime} \mathrm{N}, 7^{\circ} 18^{\prime} \mathrm{E}$ ) at the end of November 2009 and were immediately transported to the Laboratoire d'Océanographie de

10 Villefranche (LOV). Organisms were on their adult life stage (length: $1.2 \pm 0.2 \mathrm{~cm}$ ). Half of the sampled organisms $(n=400)$ were immediately placed in $5 \mathrm{I}$ experimental beakers $(n=7)$ in which they were allowed to acclimate for few hours $(\sim 3 \mathrm{~h})$ before the start of the incubations for respiration, excretion, and net calcification rates measurements. The other half was brought to the Marine Laboratories of the International 15 Atomic Energy Agency (IAEA) for measurement of gross calcification and were also placed into 7 experimental beakers $(5 \mathrm{l})$ and acclimated for few hours $(\sim 3 \mathrm{~h})$.

For each experiment (see Fig. 1 for the experimental set-up), four beakers were filled with seawater acidified by bubbling pure $\mathrm{CO}_{2}$ using a continuous $\mathrm{pH}$-stat system (IKS, Karlsbad), in order to obtain the following $p \mathrm{CO}_{2}$ levels (Fig. 1, T1 to T4): $380 \mu a$ tm $\left(\mathrm{pH}_{\mathrm{T}}=8.05\right), 760 \mu$ atm $\left(\mathrm{pH}_{\mathrm{T}}=7.80\right), 1200 \mu \mathrm{atm}\left(\mathrm{pH}_{\mathrm{T}}=7.65\right)$ and $2500 \mu$ atm $\left(\mathrm{pH}_{\mathrm{T}}=7.40\right)$. In the 3 remaining beakers, total alkalinity $\left(A_{\mathrm{T}}\right)$ was decreased by addition of $\mathrm{HCl}$ (down to about $800 \mu \mathrm{molkg}^{-1}$ ) and $\mathrm{pH}_{\mathrm{T}}$ was controlled and maintained at values of approximately 7.40, 7.80 and 8.05 (T5, T6 and T7, respectively). The two experiments were performed in temperature-controlled rooms $\left(T=19^{\circ} \mathrm{C}\right)$. At LOV, after the acclimation period, actively swimming pteropods $(n=20)$ were picked up from respective acclimation beakers, transferred to seven $250 \mathrm{ml}$ BOD bottles ( 1 bottle per condition) filled with the experimental seawaters and incubated for $20 \mathrm{~h}$. Seven extra

\section{BGD}

$9,6169-6189,2012$

\section{Effect of the carbonate chemistry on a pteropod}

S. Comeau et al.

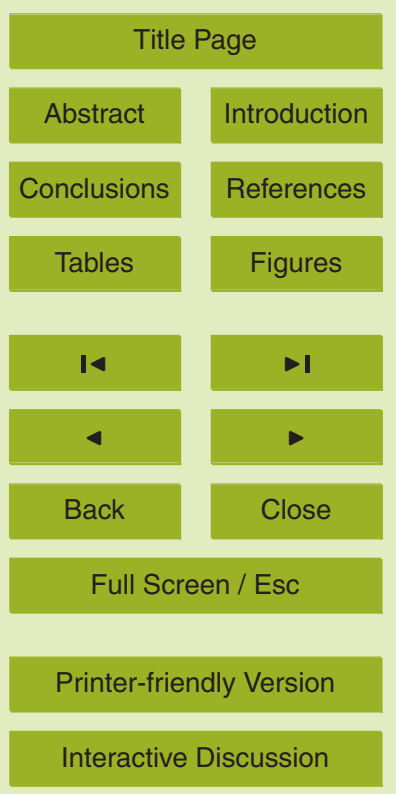


BOD bottles were only filled with the experimental seawaters and served as blanks. Due to the highly variable density of this species in the bay of Villefranche, it has not been possible to collect enough specimens in order to replicate this experiment.

Temperature, $\mathrm{pH}$ (calibrated on the total scale, thereafter referred to as $\mathrm{pH}_{\mathrm{T}}$ ) and

$5 \quad A_{\mathrm{T}}$ were measured daily in the experimental beakers at IAEA and before and after incubation at LOV. Details on the analytical techniques and on the methods used to compute the parameters of the carbonate system are available in the supplementary material.

At LOV, respiration rates $(R)$ were estimated based on oxygen uptake during the $20 \mathrm{~h}$ 10 incubation in $250 \mathrm{ml}$ BOD bottles. Oxygen $\left(\mathrm{O}_{2}\right)$ concentrations were semi-continuously recorded using a fiber-optic $\mathrm{O}_{2}$ microsensors (PreSens, Planar Oxygen-Sensitive Spot, $\varnothing=5 \mathrm{~mm}$ ). The microsensors were connected to an $\mathrm{O}_{2}$ meter (OXY-4 mini, PreSens) and calibrated using a two points calibration procedure, in aerated seawater $(100 \%$ air saturation) and a solution of $0.5 \% \mathrm{Na}_{2} \mathrm{SO}_{3}$ ( $0 \%$ oxygen). $\mathrm{O}_{2}$ consumption rates $\mathrm{O}_{2}$ consumption rates in blank incubations. $\mathrm{O}_{2}$ saturation levels never fell below $70 \%$ saturation during the incubations.

Ammonium excretion rates $(E)$ were estimated as the amount of $\mathrm{NH}_{4}^{+}$released during the incubations. Samples $(20 \mathrm{ml})$ were taken in triplicates before and after incubation for each treatment (including blanks), filtered on $0.2 \mu \mathrm{m}$ and stored at $-20^{\circ} \mathrm{C}$ pending measurements (within 2 months). $\mathrm{NH}_{4}^{+}$concentrations were measured in triplicates using a classical colorimetric technique (Koroleff, 1983) and a JenWay 6310 (Staffordshire, UK) fluorometer. Excretion rates were corrected for changes in $\mathrm{NH}_{4}^{+}$in the "blank" incubations.

$25 \quad$ Net calcification rates were estimated using an adaptation of the alkalinity anomaly technique (Smith and Key, 1975), taking into account the contribution of $\mathrm{NH}_{4}^{+}$excretion on changes in $A_{\mathrm{T}}$ (1:1 molar ratio; Wolf-Gladrow et al., 2007). Net calcification rates
BGD

$9,6169-6189,2012$

\section{Effect of the carbonate chemistry on a pteropod}

S. Comeau et al.

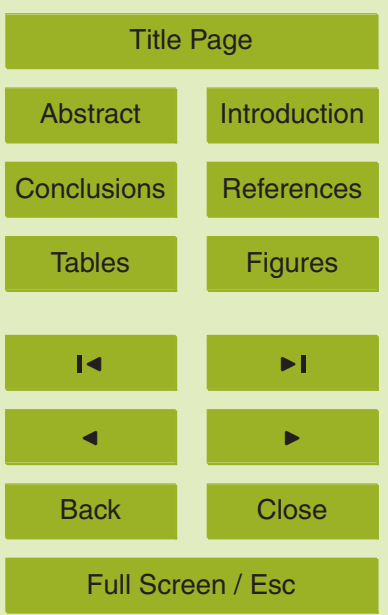

Printer-friendly Version

Interactive Discussion 
$\left(g_{\text {net }}\right)$ were calculated as:

$g_{\text {net }}=\frac{\Delta A_{\mathrm{T}}-E}{2}$

BGD

Where $\Delta A_{\mathrm{T}}$ is the variation of $A_{\mathrm{T}}$ during the incubations corrected for changes in $A_{\mathrm{T}}$ in the "blank" incubations and $E$ is the estimated excretion rate.

5 In contrast to the alkalinity anomaly technique, which provides an estimate of the balance between precipitation and dissolution of calcium carbonate, the uptake of ${ }^{45} \mathrm{Ca}$ provides an estimate of the amount of $\mathrm{CaCO}_{3}$ precipitated at the edge of the shell and therefore refers to gross calcification. At IAEA, in order to measure gross calcification rates $\left(g_{\text {gross }}\right), 5 \mathrm{~L}$ beakers, containing seawater for the different treatments, were spiked with ${ }^{45} \mathrm{CaCl}_{2}\left(50 \mathrm{~Bq} \mathrm{ml}^{-1}\right)$. The 7 beakers were filled with 60 pteropods each that served for both time points 0 and $48 \mathrm{~h}$. Counting of radioactivity were performed on the shells of 10 pteropods sampled in triplicates per treatment and time points. An identical protocol was used under the same conditions on pteropods killed by freezing prior to incubation in order to estimate the non-biological incorporation of ${ }^{45} \mathrm{Ca}$ in the shell (Comeau et al., 15 2009).

Details on the procedure applied to normalize the rates of the different investigated processes to the weight of the incubated organisms as well as details on the statistics used to analyze the obtained dataset can be found in the supplementary material.

\section{Results}

20 During the LOV experiment, $\mathrm{pH}_{\mathrm{T}}$ at which organisms were exposed during the incubations varied between $8.02 \pm 0.04$ in T1 (control) and $7.39 \pm 0.02$ in T4 (Table 1). $A_{\mathrm{T}}$ was successfully decreased close to the targeted value of $800 \mu \mathrm{molkg}^{-1}$, respectively, $804.7 \pm 2.0,792.3 \pm 3.9$ and $793.6 \pm 2.7 \mu \mathrm{molkg}^{-1} . \ln \mathrm{T} 1, \mathrm{~T} 2$ and T3 seawater was oversaturated with respect to aragonite with mean $\Omega_{a}$ of $3.1 \pm 0.1,2.2 \pm 0.1$ and $1.2 \pm 0.1$, respectively. The seawater of the 4 other treatments was undersaturated with respect

\section{Effect of the carbonate chemistry on a pteropod}

S. Comeau et al.

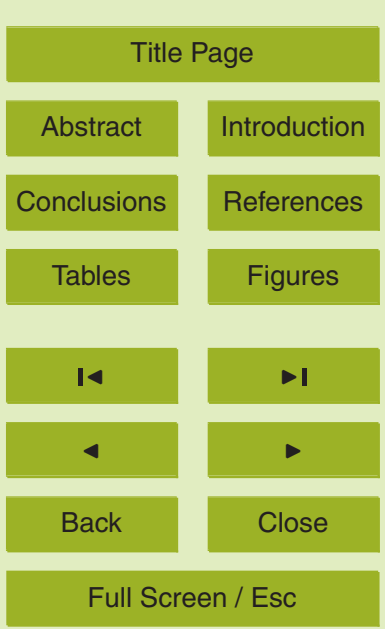

Printer-friendly Version

Interactive Discussion 
to aragonite with mean $\Omega_{a}$ of $0.9 \pm 0.0,0.3 \pm 0.0,0.6 \pm 0.0$ and $0.9 \pm 0.0$ in T4, T5, T6 and T7, respectively. Very similar values were observed for each treatment during the IAEA experiment (Table 2). $\mathrm{pH}_{\mathrm{T}}$ varied between $8.08 \pm 0.03$ in $\mathrm{T} 7$ and $7.42 \pm 0.01$ in T4. As for the LOV experiment, seawater was oversaturated with respect to aragonite in $5 \mathrm{~T} 1, \mathrm{~T} 2$ and T3 $\left(\Omega_{\mathrm{a}}=3.3 \pm 0.1,2.0 \pm 0.0\right.$ and $1.6 \pm 0.1$, respectively $)$ and undersaturated in the other treatments $\left(\Omega_{\mathrm{a}}=0.9 \pm 0.0,0.3 \pm 0.0,0.6 \pm 0.0\right.$ and $0.9 \pm 0.0$ in T4, T5, T6 and $T 7$, respectively).

The highest rates of respiration were measured in the control treatment $\left(\mathrm{T} 1, A_{\mathrm{T}} \sim\right.$ $2563 \mu \mathrm{molkg}^{-1}, \mathrm{pH}_{\mathrm{T}} \sim 8.0 ; 72.5 \pm 0.3 \mu \mathrm{molO}_{2} \mathrm{gDW}^{-1} \mathrm{~h}^{-1}$ ), and the lowest rates were o obtained in T7 $\left(A_{\mathrm{T}} \sim 794 \mu \mathrm{mol} \mathrm{kg}^{-1}, \mathrm{pH}_{\mathrm{T}} \sim 8.0 ; 37.4 \pm 0.5 \mu \mathrm{molO}_{2} \mathrm{gDW}^{-1} \mathrm{~h}^{-1}\right)$. Linear regression revealed no significant effect of $\mathrm{pH}_{\mathrm{T}}$ on respiration rates (Student's $t$-test, $p=0.43, n=7$, Fig. 2a) while a statistically significant linear decline of respiration rates was observed as a function of decreasing $\Omega_{\mathrm{a}}$ levels $\left(R=33.8+11.5 \times \Omega_{\mathrm{a}} ; r^{2}=0.88\right.$, Student's $t$-test, $n=7, p=0.002$, Fig. 2b). Ammonium excretion rates varied be15 tween $17.1 \pm 3.1 \mu \mathrm{molNH} \mathrm{NDW}^{+1} \mathrm{~h}^{-1}$ in T1 (control) and 3.5 $\pm 2.2 \mu \mathrm{molNH}_{4}^{+} \mathrm{gDW}^{-1} \mathrm{~h}^{-1}$ in $\mathrm{T} 5\left(A_{\mathrm{T}} \sim 805 \mu \mathrm{molkg}^{-1}, \mathrm{pH}_{\mathrm{T}} \sim 7.4\right)$. As for respiration, there was no significant relationship between $\mathrm{pH}_{\mathrm{T}}$ and excretion rates (Student's $t$-test, $p=0.056, n=7$, Fig. 2c) while a statistically significant linear decline of excretion rates was observed as a function of decreasing $\Omega_{\mathrm{a}}$ levels $\left(E=3-4.2 \times \Omega_{\mathrm{a}} ; r^{2}=0.86\right.$, Student's $20 t$-test, $p=0.003, n=7$, Fig. 2d). Positive rates of net calcification $(2.4 \pm 2.4$ and $3.1 \pm 1.6 \mu \mathrm{mol} \mathrm{CaCO}_{3} \mathrm{gDW}^{-1} \mathrm{~h}^{-1}$, respectively) were measured in $\mathrm{T} 1$ (control) and $\mathrm{T} 2$ $\left(A_{\mathrm{T}} \sim 2633 \mu \mathrm{molkg}^{-1}, \mathrm{pH}_{\mathrm{T}} \sim 7.8\right)$. In the other treatments, negative net calcification rates were measured with the lowest value of $-29.9 \pm 2.0 \mu \mathrm{mol} \mathrm{CaCO}_{3} \mathrm{gDW}^{-1} \mathrm{~h}^{-1}$ found in T5. As for respiration and excretion rates, $\mathrm{pH}_{\mathrm{T}}$ had no significant effect on net calcification rates (Student's $t$-test, $p=0.31, n=7$, Fig. $2 \mathrm{e}$ ). Net calcification rates were not linearly related to $\Omega_{\mathrm{a}}$, and a saturating hyperbolic function was used to fit the data $\left(g_{\text {net }}=57 \times\left(1-\exp ^{\left(-\Omega_{\mathrm{a}} / 0.6\right)}\right)-53.1 ; p<0.01, n=7\right.$, Fig. $\left.2 \mathrm{f}\right)$. The release of $\mathrm{NH}_{4}^{+}$by excretion of the organisms explained between 5.6 and $78.1 \%$ of the changes in $A_{\mathrm{T}}$
BGD

9, 6169-6189, 2012

\section{Effect of the carbonate chemistry on a pteropod}

S. Comeau et al.

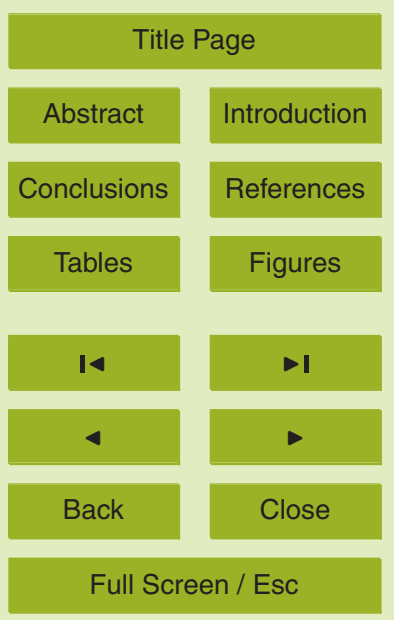

Printer-friendly Version

Interactive Discussion 
during the incubations. The highest rate of gross calcification was measured in the control treatment $\left(\mathrm{T} 1 ; 0.8 \pm 0.1 \mu \mathrm{molCaCO}_{3} \mathrm{gDW}^{-1} \mathrm{~h}^{-1}\right)$ and no active $\mathrm{CaCO}_{3}$ precipitation occurred in T5, T6 and T7 corresponding to $\Omega_{\mathrm{a}}$ levels below 1. No significant relationship was found between $g_{\text {gross }}$ and $\mathrm{pH}_{\mathrm{T}}$ (Fig. 3a). Gross calcification rates 5 were not linearly related to $\Omega_{\mathrm{a}}$, and a logarithmic function was used to fit the data $\left(g_{\text {gross }}=0.39 \times \ln \left(\Omega_{\mathrm{a}}\right)+0.3 ; p<0.01, n=7\right.$, Fig. 3b $)$.

\section{Discussion}

This is the first study on the effects of ocean acidification on physiological rates of an adult Mediterranean pteropod. The respiration of $C$. acicula was not significantly 10 impacted by $\mathrm{pH}_{\mathrm{T}}$ but decreased as a function of decreasing $\Omega_{\mathrm{a}}$. Fabry et al. (2008) mention a $25 \%$ decrease of the respiration of the Antarctic pteropod Limacina helicina antarctica incubated at $789 \mu$ atm as compared to "control" conditions although information on the carbonate chemistry and on the time the organisms have been incubated were not presented. Comeau et al. (2010b) have shown that the respiration rates of 15 Limacina helicina were unaffected by a decrease in $\mathrm{pH}$ at in situ temperature but increased significantly with decreasing $\mathrm{pH}$ when placed at a higher temperature $\left(+4^{\circ} \mathrm{C}\right)$. Maas et al. (2012) studied the respiration rate of 5 tropical pteropod species, among which four were used to migrate through an Oxygen Minimum Zone (OMZ). These migrating species were unaffected by decreasing $\mathrm{pH}$ levels whereas respiration rate of the non-migrating species was depressed at lower $\mathrm{pH}$. In the present study, decreases of respiration rates were also found under perturbed conditions, although the observed decrease in respiration rates was better correlated with $\Omega_{\mathrm{a}}$ than with seawater $\mathrm{pH}_{\mathrm{T}}$. The mechanisms responsible for the observed decrease in respiration rates with decreasing $\Omega_{a}$ remain unknown but might be linked to changes in acid-base balance, notably due to a disruption of ion transportations (e.g., Portner et al., 2005).

Our study showed that $C$. acicula excretion rates and $\Omega_{a}$ are significantly correlated, whereas $\mathrm{pH}$ does not have a significant effect. Reports on the effects of

\section{BGD}

9, 6169-6189, 2012

\section{Effect of the carbonate chemistry on a pteropod}

S. Comeau et al.

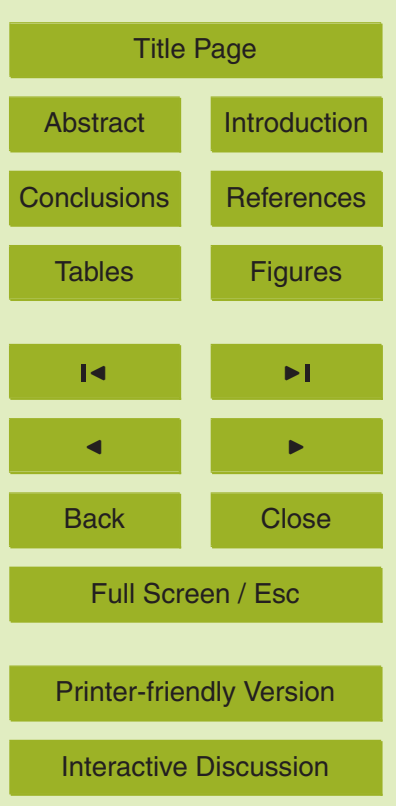


ocean acidification on excretion rates of marine organisms are very scarce. Michaelidis et al. (2005) showed a significant increase of Mytilus galloprovincialis excretion rates at low $\mathrm{pH}\left(\mathrm{pH}_{\mathrm{NBS}} 7.3\right)$ as compared to control conditions $\left(\mathrm{pH}_{\mathrm{NBS}} 8.05\right)$ both in the short (hours) and the long-term (months). Maas et al. (2012) demonstrated that the excretion rate of the non-migrating pteropod (Diacria quadridentata) was depressed by lower $\mathrm{pH}$ whereas the rates of species crossing the $\mathrm{OMZ}$ were unaffected. As for respiration rates, our data partly confirm the findings of Mass et al. (2012), although excretion rates were not found to be directly correlated to $\mathrm{pH}_{\mathrm{T}}$ and declined linearly with decreasing $\Omega_{a}$.

10 In the present study, it has been shown that both net and gross calcification rates of $C$. acicula are mainly governed by $\Omega_{\mathrm{a}}$, whereas $\mathrm{pH}_{\mathrm{T}}$ does not have a significant effect. Jury et al. (2010) used a similar approach, based on manipulations of the seawater carbonate chemistry, to determine which parameter controls coral calcification. They showed that the calcification rate of Madracis auretenra in the light was mainly governed by the bicarbonate ion concentration $\left[\mathrm{HCO}_{3}^{-}\right]$and not, as expected, by $\Omega_{\mathrm{a}}$. In the present study, $\left[\mathrm{HCO}_{3}^{-}\right]$is not correlated with any of the physiological processes measured (data not shown). At $\Omega_{a}$ above 1 , net calcification rates were very close to 0 and no significant differences could be highlighted with increasing $\Omega_{\mathrm{a}}$ levels. The fact that the computation of net calcification rates is based on several measurements 20 (see supplementary Material and Methods), the propagation of errors associated with these measurements explains the non-significance of the low net calcification signal measured at $\Omega_{a}$ above 1 . Since gross calcification rates increased with increasing $\Omega_{a}$ levels above 1 (see thereafter), it appears that the alkalinity anomaly technique, as used in the present study, does not have the resolution required to estimate net calcicalcification rates were related to $\Omega$ levels through a saturating hyperbolic function with no significant effect above $\Omega_{a}=1$. Below saturation, net calcification rates were negative and strongly declined with decreasing $\Omega_{a}$ values.

\section{BGD}

9, 6169-6189, 2012

\section{Effect of the carbonate chemistry on a pteropod}

S. Comeau et al.

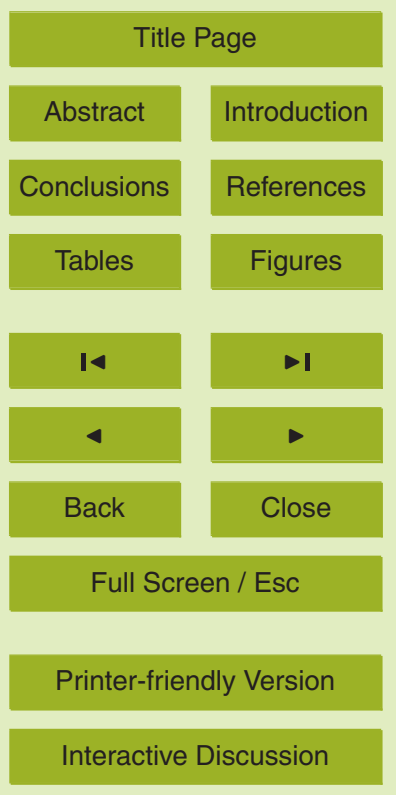


The ${ }^{45} \mathrm{Ca}$ uptake experiment also showed that $\Omega_{\mathrm{a}}$ rather than $\mathrm{pH}$ is a major control of gross calcification. Precipitation of $\mathrm{CaCO}_{3}$ did not occur at low $\Omega_{\mathrm{a}}$ values and gross calcification rates increased with increasing $\Omega_{a}$ levels for $\Omega_{a}$ above 1 . Gross calcification rates were $30 \%$ lower at a $p \mathrm{CO}_{2}$ level close to the ones projected for the end of 5 the century $(880 \mu \mathrm{atm}, \mathrm{T2})$ than in the control. Although this ${ }^{45} \mathrm{Ca}$ uptake technique appeared accurate enough to estimate gross calcification rates for this pteropod species, it must be stressed that, in contrast to the alkalinity anomaly technique, it does not allow an estimation of dissolution rates. The lack of $\mathrm{CaCO}_{3}$ precipitation in $\mathrm{T} 7$ as compared to $\mathrm{T} 4$, corresponding to the same concentration of $\mathrm{CO}_{3}^{2-}$ but a lower concentration of $10 \mathrm{HCO}_{3}^{-}$suggests that, even though $\mathrm{HCO}_{3}^{-}$is not the driving parameter, it plays a role in calcification. Indeed, $\left[\mathrm{HCO}_{3}^{-}\right]$was $\sim 4$ times higher in $\mathrm{T} 4$ than in $\mathrm{T} 7$, suggesting that $\mathrm{HCO}_{3}^{-}$can be used as a secondary carbon source for calcification under low $\mathrm{CO}_{3}^{2-}$ conditions. During the IAEA experiment as well as in a previous study (Comeau et al., $2010 b$ ), the significant incorporation of ${ }^{45} \mathrm{Ca}$ in slightly undersaturated waters demon15 strates that pteropods are still able to precipitate calcium carbonate below the aragonite saturation level. Nevertheless, following net calcification rates estimated during the LOV experiment, the clear dissolution signal measured at $\Omega_{\mathrm{a}} \sim 0.9$, demonstrates that these regulating capabilities are overtaken by dissolution and do not enable to reach positive net calcification rates.

20 In the present study, both $g_{\text {net }}$ and $g_{\text {gross }}$ of $C$. acicula appeared mainly governed by $\Omega_{\mathrm{a}}$, whereas $\mathrm{pH}$ and $\left[\mathrm{HCO}_{3}^{-}\right]$(result not shown) did not have a clear direct effect. Similar results have been found on the Pacific oyster Crassostreas gigas in which larval developmental success and growth rates were not affected by the $\mathrm{pH}$ or $\left[\mathrm{HCO}_{3}^{-}\right]$, whereas they were correlated to $\left[\mathrm{CO}_{3}^{2-}\right]$ and its associated $\Omega_{\mathrm{a}}$ (Gazeau et al., 2011). 25 The situation is less clear in zooxanthellate scleractinian corals in which numerous studies have brought contradictory results (for an extensive review see Allemand et al., 2010).

BGD

$9,6169-6189,2012$

\section{Effect of the carbonate chemistry on a pteropod}

S. Comeau et al.

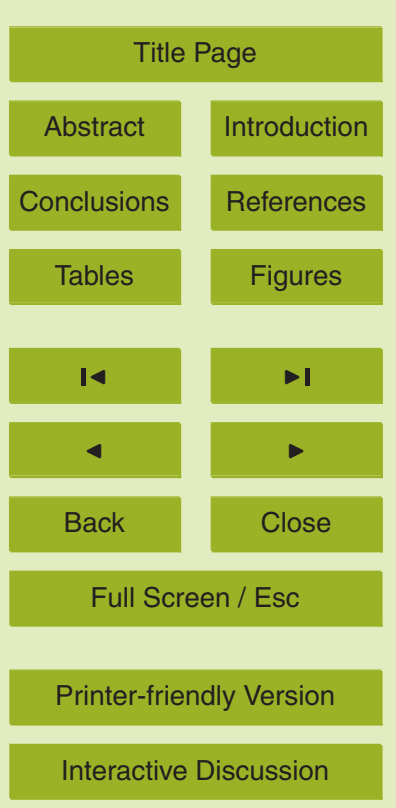


Previous studies on the Arctic pteropod L. helicina have shown similar relationship between gross calcification and $\Omega_{\mathrm{a}}$. However, the present low $\Omega_{\mathrm{a}}$ recorded in this region (e.g., Yamamoto-Kawai et al., 2009) suggests a higher exposure of high latitude pteropods to declining $\Omega_{a}$ (Comeau et al., 2011). Orr et al. (2005) projected that the 5 surface water of the Southern Ocean will become undersaturated with respect to aragonite by the year 2050. The situation is even more severe in the Arctic Ocean where model projections indicate an aragonite undersaturation, on an annual average, over $10 \%$ of its area by the year 2023 (Steinacher et al., 2009).

The situation is less dramatic in the Mediterranean Sea as, for example, $\Omega_{a}$ values never fall below 2.9 on an annual basis in the surface waters of the bay of Villefranche (NW Mediterranean; data not shown). It results that, in contrast to high-latitude species, Mediterranean species such as $C$. acicula will experience a decrease in saturation state but will not be exposed to aragonite undersaturated conditions in the coming decades (Orr, 2011).

\section{Conclusions}

The strong relations observed between physiological processes and $\Omega_{a}$, as well as the fact that organisms appear unable to produce a shell under corrosive conditions, suggest that future decrease in $\Omega_{a}$ will impact pteropods populations, particularly high latitudes ones, as well as the ecosystems in which they play a critical role. However,

20 it must be stressed that, as Creseis acicula, using the current techniques, can only be maintained alive for few days in the laboratory, these experiments were conducted on animals acclimated only for few hours. Similarly Maas et al. (2012), based also their work on animals acclimated for few hours, and stressed out that the observed response of an organisms to hypercapnia in short-term might differ from a longer-term are necessary in order to perform long-term experiments allowing an assessment of their potential acclimation capacity to low $\Omega_{a}$ conditions. Nevertheless, despite these

BGD

$9,6169-6189,2012$

\section{Effect of the carbonate chemistry on a pteropod}

S. Comeau et al.

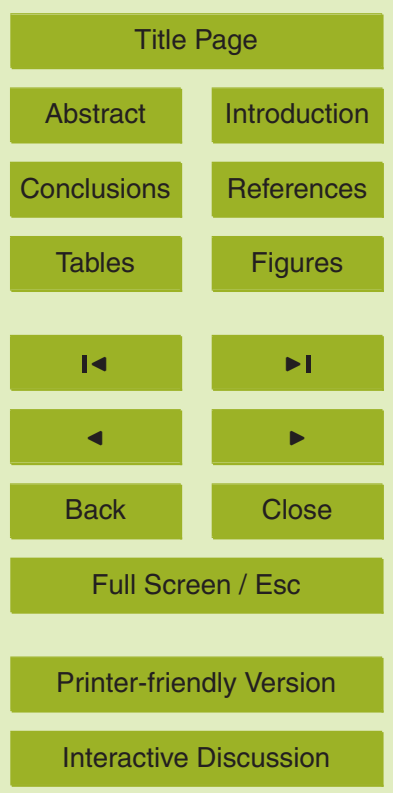


limitations, the present study represents an important additional step in our understanding of pteropods physiology under ocean acidification scenarios.

\section{Supplementary material related to this article is available online at: http://www.biogeosciences-discuss.net/9/6169/2012/ bgd-9-6169-2012-supplement.pdf.}

Acknowledgements. This work is a contribution to the "European Project on Ocean Acidification" (EPOCA) which received funding from the European Community's Seventh Framework Programme (FP7/2007-2013) under grant agreement $n^{\circ} 211384$. This work received also funding from the "Fondation Total" through the REMECCA project. The IAEA is grateful for the support provided to its Marine Environment Laboratories by the Government of the Principality of Monaco.

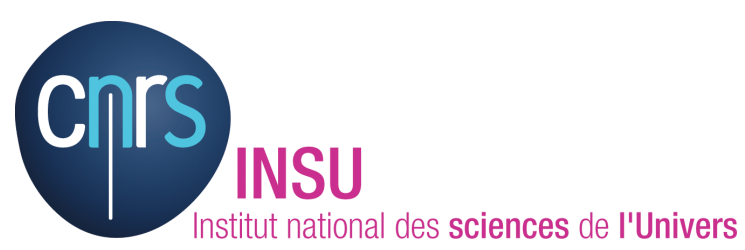

The publication of this article is financed by CNRS-INSU.

\section{References}

Allemand, D., Tambutté, E., Zoccola, D., and Tambutté, S.: Coral calcification, cells to reefs, in: Coral Reefs: an Ecosystem in Transition, edited by: Dubinsky, Z. and Stambler, N., Springer, Dordrecht, 119-150, 2010.

Bé, A. W. H. and Gilmer, R. W.: A zoogeographic and taxonomic review of euthecosomatous
BGD

$9,6169-6189,2012$

Effect of the carbonate chemistry on a pteropod

S. Comeau et al.

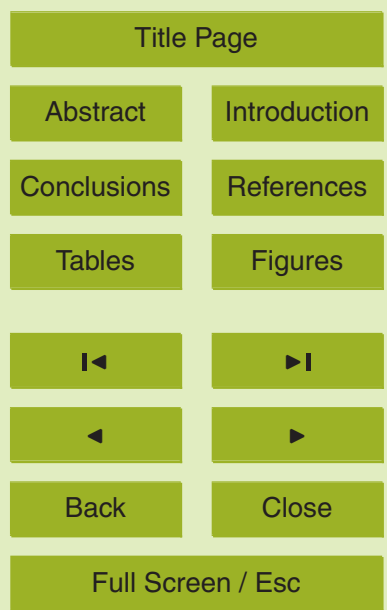

Printer-friendly Version

Interactive Discussion 
Berner, R. A. and Honjo, S.: Pelagic sedimentation of aragonite: its geochemical significance, Science, 3, 940-942, 1981.

Comeau, S., Gorsky, G., Jeffree, R., Teyssié, J.-L., and Gattuso, J.-P.: Impact of ocean acidification on a key Arctic pelagic mollusc (Limacina helicina), Biogeosciences, 6, 1877-1882,

5 doi:10.5194/bg-6-1877-2009, 2009.

Comeau, S., Alliouane, S., Gorsky, G., and Gattuso, J.-P.: Larvae of the pteropod Cavolinia inflexa are viable but shell-less, Mar. Biol., 157, 2341-2345, 2010a.

Comeau, S., Jeffree, R., Teyssié, J.-L., and Gattuso, J.-P.: Response of the Arctic pteropod Limacina helicina to projected future environmental conditions, PLoS One, 5, e11362, doi:10.1371/journal.pone.0011362, 2010b.

Comeau, S., Gattuso, J.-P., Nisumaa, A.-M., and Orr, J. C.: Impact of aragonite saturation state changes on migratory pteropods, P. Roy. Soc.-Biol. Sci., 279, 732-=738, 2012.

Fabry, V. J., Seibel, B. A., Feely, R. A., and Orr, J. C.: Impacts of ocean acidification on marine fauna and ecosystem processes, ICES J. Mar. Sci., 65, 414-432, 2008.

15 Gazeau, F., Quiblier, C., Jansen, J. M., Gattuso, J.-P., Middelburg, J. J., and Heip, C. H. R.: Impact of elevated $\mathrm{CO}_{2}$ on shellfish calcification, Geophys. Res. Lett., 34, L07603, doi:10.1029/2006GL02855, 2007.

Gazeau, F., Gattuso, J.-P., Greaves, M., Elderfield, H., Peene, J., Heip, C. H. R., and Middelburg, J. J.: Effect of carbonate chemistry alteration on the early embryonic development of the Pacific Oyster (Crassostrea gigas), PLoS One, 6, e23010, doi:10.1371/journal.pone.0023010, 2011.

Hunt, B. P., Pakhomov, E. A., Hosie, G. W., Siegel, V., Ward, P., and Bernard, K.: Pteropods in Southern Ocean ecosystems, Prog. Oceanogr., 78, 193-221, 2008.

Iglesias-Rodriguez, M. D., Halloran, P. R., Rickaby, R. E. M., Hall, I. R., Colmenero-Hidalgo, E., Gittins, J. R., Green, D. R. H., Tyrrell, T., Gibbs, S. J., von Dassow, P., Rehm, E., Armbrust E. V. and Boessenkool, K. P.: Phytoplankton calcification in a high- $\mathrm{CO}_{2}$ world, Science, 320, 336-340, 2008.

Jury, C. P., Whitehead, R. F., and Szmant, A. M.: Effects of variations in carbonate chemistry on the calcification rates of Madracis auretenra (= Madracis mirabilis sensu Wells, 1973): bicarbonate concentrations best predict calcification rates, Glob. Change. Biol., 16, 16321644, 2010.

Koroleff, F.: Determination of ammonia, in: Methods of Seawater Analysis, 2nd edn., edited by: Grasshoff, K., Ehrhardt, M., and Kremling, F., Verlag Chemie, Weinheim, 150-157, 1983.

\section{BGD}

$9,6169-6189,2012$

\section{Effect of the carbonate chemistry on a pteropod}

S. Comeau et al.

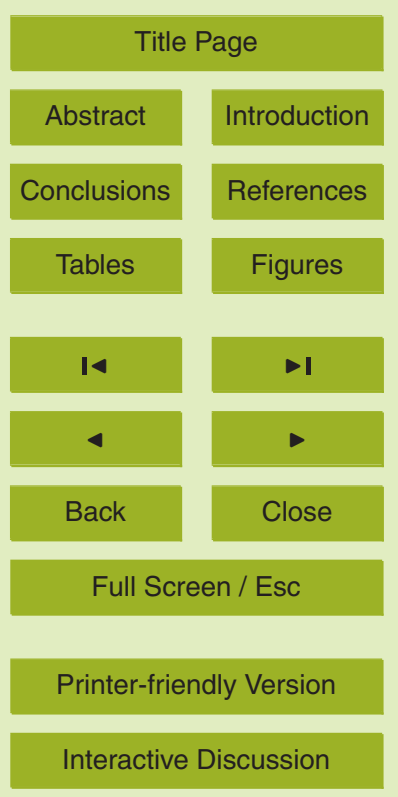


Lalli, C. M. and Gilmer, R. W.: Pelagic Snails, the Biology of Holoplanktonic Gastropod Mollusks, Stanford University Press, Stanford, California, 1989.

Langdon, C. and Atkinson, M. J.: Effect of elevated $p \mathrm{CO}_{2}$ on photosynthesis and calcification of corals and interactions with seasonal change in temperature/irradiance and nutrient enrichment, J. Geophys. Res., 110, C09S07, doi:10.1029/2004JC002576, 2005.

Lavigne, H. and Gattuso, J.-P.: Seacarb: seawater carbonate chemistry with R. R package version 2.4.1, http://CRAN.Rproject.org/package=seacarb, 2011.

Lischka, S., Büdenbender, J., Boxhammer, T., and Riebesell, U.: Impact of ocean acidification and elevated temperatures on early juveniles of the polar shelled pteropod Limacina helicina: mortality, shell degradation, and shell growth, Biogeosciences, 8, 919-932, doi:10.5194/bg8-919-2011, 2011.

Maas, A. E., Wishner, K. F., and Seibel, B. A.: The metabolic response of pteropods to acidification reflects natural $\mathrm{CO}_{2}$-exposure in oxygen minimum zones, Biogeosciences, 9, 747-757, doi:10.5194/bg-9-747-2012, 2012.

Michaelidis, B., Ouzounis, C., Paleras A., and Pörtner, H. O.: Effects of long-term moderate hypercapnia on acid-base balance and growth rate in marine mussels Mytilus galloprovincialis, Mar. Ecol. Prog. Ser., 293, 109-118, 2005.

Orr, J. C., Fabry, V. J., Aumont, O., Bopp, L., Doney, S. C., Feely, R. A., Gnanadesikan, A., Gruber, N., Ishida, A., Joos, F., Key, R. M., Lindsay, K., Maier-Reimer, E., Matear, R., Monfray, P., Mouchet, A., Najjar, R. G., Plattner, G.-K., Rodgers, K. B., Sabine, C. L., Sarmiento, J. L., Schlitzer, R., Slater, R. D., Totterdell, I. J., Weirig, M.-F., Yamanaka, Y., and Yool, A.: Anthropogenic ocean acidification over the twenty-first century and its impact on calcifying organisms, Nature, 437, 681-686, 2005.

Orr, J. C.: Recent and future changes in ocean carbonate chemistry, in: Ocean Acidification, edited by: Gattuso J.-P. and Hansson L., Oxford University Press, Oxford, 41-66, 2011.

Pörtner, H. O., Langenbuch, M., and Reipschläger, A.: Biological impact of elevated ocean $\mathrm{CO}_{2}$ concentrations: lessons from animal physiology and earth history, J. Oceanogr., 60, 705-718, 2004.

Riebesell, U., Zondervan, I., Rost, B., Tortell, P. D., Zeebe, R. E., and Morel, F. M. M.: Reduced calcification of marine plankton in response to increased atmospheric $\mathrm{CO}_{2}$, Nature, 407, 364-367, 2000.

Ries, J. B., Cohen, A. L., and McCorkle, D. C.: Marine calcifiers exhibit mixed responses to $\mathrm{CO}_{2}$-induced ocean acidification, Geology, 37, 1131-1134, 2009. 
Sabine, C. L., Feely, R. A., Gruber, N., Key, R. M., Lee, K., and Bullister, J. L.: The oceanic sink for anthropogenic $\mathrm{CO}_{2}$, Science, 305, 367-371, 2004.

Smith, S. V. and Key, G. S.: Carbon dioxide and metabolism in marine environments, Limnol. Oceanogr., 20, 493-495, 1975.

5 Steinacher, M., Joos, F., Frölicher, T. L., Plattner, G.-K., and Doney, S. C.: Imminent ocean acidification in the Arctic projected with the NCAR global coupled carbon cycle-climate model, Biogeosciences, 6, 515-533, doi:10.5194/bg-6-515-2009, 2009.

Wolf-Gladrow, D., Zeebe, R., Klaas, C., Kortzinger, A., and Dickson, A.: Total alkalinity: The explicit conservative expression and its application to biogeochemical processes, Mar. Chem., 106, 287-300, 2007.

Yamamoto-Kawai, M., McLaughlin, F. A., Carmack, E. C., Nishino, S., and Shimada, K.: Aragonite undersaturation in the Arctic Ocean: Effects of ocean acidification and sea ice melt, Science, 326, 1098-1100, 2009.

\section{BGD}

$9,6169-6189,2012$

\section{Effect of the carbonate chemistry on a pteropod}

S. Comeau et al.

Title Page

\section{Abstract}

Introduction

Conclusions

References

Tables

Figures

14

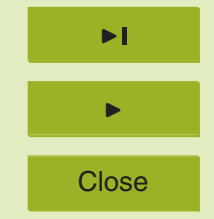

Back

Close

Printer-friendly Version

Interactive Discussion 


\section{Effect of the carbonate chemistry on a pteropod}

Table 1. Carbonate chemistry of the seawater used to measure rates of net calcification, respiration and excretion (LOV experiment). Temperature, $\mathrm{pH}_{\mathrm{T}}$ and total alkalinity $\left(A_{\mathrm{T}}\right.$, in triplicates) were measured before and after incubation, averaged values (SD) are shown. Dissolved inorganic carbon $\left(C_{\mathrm{T}}\right)$ concentration, the partial pressure of $\mathrm{CO}_{2}\left(\mathrm{pCO}_{2}\right)$ and the saturation state of seawater with respect to aragonite and calcite $\left(\Omega_{\mathrm{a}}\right.$ and $\Omega_{\mathrm{c}}$, respectively) were calculated using seacarb (Lavigne and Gattuso 2011) and given as mean (SD).

\begin{tabular}{lrrrrrrr}
\hline Treatment & $\begin{array}{r}T \\
\left({ }^{\circ} \mathrm{C}\right)\end{array}$ & $\mathrm{pH}_{\mathrm{T}}$ & $\begin{array}{r}A_{\mathrm{T}} \\
\left(\mu \mathrm{mol} \mathrm{kg}^{-1}\right)\end{array}$ & $\begin{array}{r}C_{\mathrm{T}} \\
\left(\mu \mathrm{molkg}^{-1}\right)\end{array}$ & $\begin{array}{r}\mathrm{pCO}_{2} \\
(\mu \mathrm{atm})\end{array}$ & $\Omega_{\mathrm{a}}$ & $\Omega_{\mathrm{c}}$ \\
\hline T1 & $19.3(0.2)$ & $8.02(0.04)$ & $2562.8(1.9)$ & $2287.1(14.3)$ & $475(32)$ & $3.1(0.1)$ & $4.7(0.2)$ \\
T2 & $19.6(0.7)$ & $7.82(0.03)$ & $2633.4(1.6)$ & $2456.9(9.7)$ & $835(42)$ & $2.2(0.1)$ & $3.3(0.1)$ \\
T3 & $19.3(0.2)$ & $7.54(0.05)$ & $2625.9(1.6)$ & $2566.6(10.3)$ & $1671(113)$ & $1.2(0.1)$ & $1.8(0.1)$ \\
T4 & $19.3(0.2)$ & $7.39(0.02)$ & $2618.0(2.7)$ & $2615.6(4.0)$ & $2427(59)$ & $0.9(0.0)$ & $1.3(0.0)$ \\
T5 & $18.9(0.1)$ & $7.43(0.01)$ & $804.7(2.0)$ & $781.0(1.3)$ & $654(5)$ & $0.3(0.0)$ & $0.4(0.0)$ \\
T6 & $19.3(0.1)$ & $7.81(0.05)$ & $792.3(3.9)$ & $700.2(6.1)$ & $240(17)$ & $0.6(0.0)$ & $0.9(0.0)$ \\
T7 & $18.8(0.0)$ & $8.02(0.05)$ & $793.6(2.7)$ & $651.6(9.0)$ & $134(12)$ & $0.9(0.0)$ & $1.3(0.1)$ \\
\hline
\end{tabular}

S. Comeau et al.

Title Page

Abstract

Introduction

Conclusions

References

Tables

Figures

14

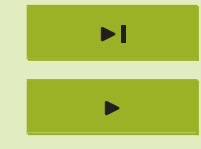

Back

Close

\section{Full Screen / Esc}

Printer-friendly Version

Interactive Discussion 


\section{Effect of the carbonate chemistry on a pteropod}

Table 2. Carbonate chemistry of the seawater used to measure rates of ${ }^{45} \mathrm{Ca}$ incorporation (IAEA experiment). Temperature $(T)$ and $\mathrm{pH}_{\mathrm{T}}$ were measured on 4 occasions during the $48 \mathrm{~h}$ incubations while total alkalinity $\left(A_{T}\right)$ was measured in triplicates at the start of the incubations; averaged values (SD) are shown. Dissolved inorganic carbon $\left(C_{\mathrm{T}}\right)$ concentration, the partial pressure of $\mathrm{CO}_{2}\left(p \mathrm{CO}_{2}\right)$ and the saturation state of seawater with respect to aragonite and calcite $\left(\Omega_{\mathrm{a}}\right.$ and $\Omega_{\mathrm{c}}$, respectively) were calculated using seacarb and are given as mean (SD).

\begin{tabular}{lrrrrrrr}
\hline Treatment & $\begin{array}{r}T \\
\left({ }^{\circ} \mathrm{C}\right)\end{array}$ & $\mathrm{pH}_{\mathrm{T}}$ & $\begin{array}{r}A_{\mathrm{T}} \\
\left(\mu \mathrm{mol} \mathrm{kg}^{-1}\right)\end{array}$ & $\begin{array}{r}C_{\mathrm{T}} \\
\left(\mu \mathrm{molkg}^{-1}\right)\end{array}$ & $\begin{array}{r}p \mathrm{CO}_{2} \\
(\mu \mathrm{atm})\end{array}$ & $\Omega_{\mathrm{a}}$ & $\Omega_{\mathrm{c}}$ \\
\hline $\mathrm{T} 1$ & $19.2(0.2)$ & $8.06(0.04)$ & $2587.8(0.3)$ & $2284.5(14.3)$ & $426(27)$ & $3.3(0.1)$ & $5.1(0.2)$ \\
$\mathrm{T} 2$ & $19.6(0.3)$ & $7.79(0.01)$ & $2582.2(2.0)$ & $2423.2(3.1)$ & $876(13)$ & $2.0(0.0)$ & $3.0(0.0)$ \\
$\mathrm{T} 3$ & $19.5(0.1)$ & $7.68(0.05)$ & $2576.8(4.2)$ & $2463.4(12.2)$ & $1164(85)$ & $1.6(0.1)$ & $2.4(0.1)$ \\
$\mathrm{T} 4$ & $19.2(0.2)$ & $7.42(0.01)$ & $2572.3(1.4)$ & $2558.1(2.3)$ & $2202(31)$ & $0.9(0.0)$ & $1.4(0.0)$ \\
$\mathrm{T} 5$ & $19.5(0.1)$ & $7.44(0.01)$ & $761.8(3.1)$ & $735.5(2.0)$ & $606(9)$ & $0.3(0.0)$ & $0.4(0.0)$ \\
$\mathrm{T} 6$ & $19.5(0.2)$ & $7.82(0.02)$ & $774.6(1.5)$ & $681.1(2.7)$ & $229(7)$ & $0.6(0.0)$ & $0.9(0.0)$ \\
$\mathrm{T} 7$ & $19.5(0.3)$ & $8.08(0.03)$ & $764.5(0.8)$ & $605.5(5.2)$ & $108(6)$ & $0.9(0.0)$ & $1.4(0.0)$ \\
\hline
\end{tabular}

S. Comeau et al.

Title Page

Abstract

Introduction

Conclusions

References

Tables

Figures

14

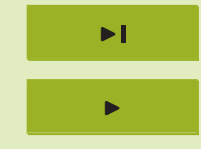

Back

Close

\section{Full Screen / Esc}

Printer-friendly Version

Interactive Discussion

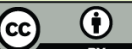


BGD

$9,6169-6189,2012$

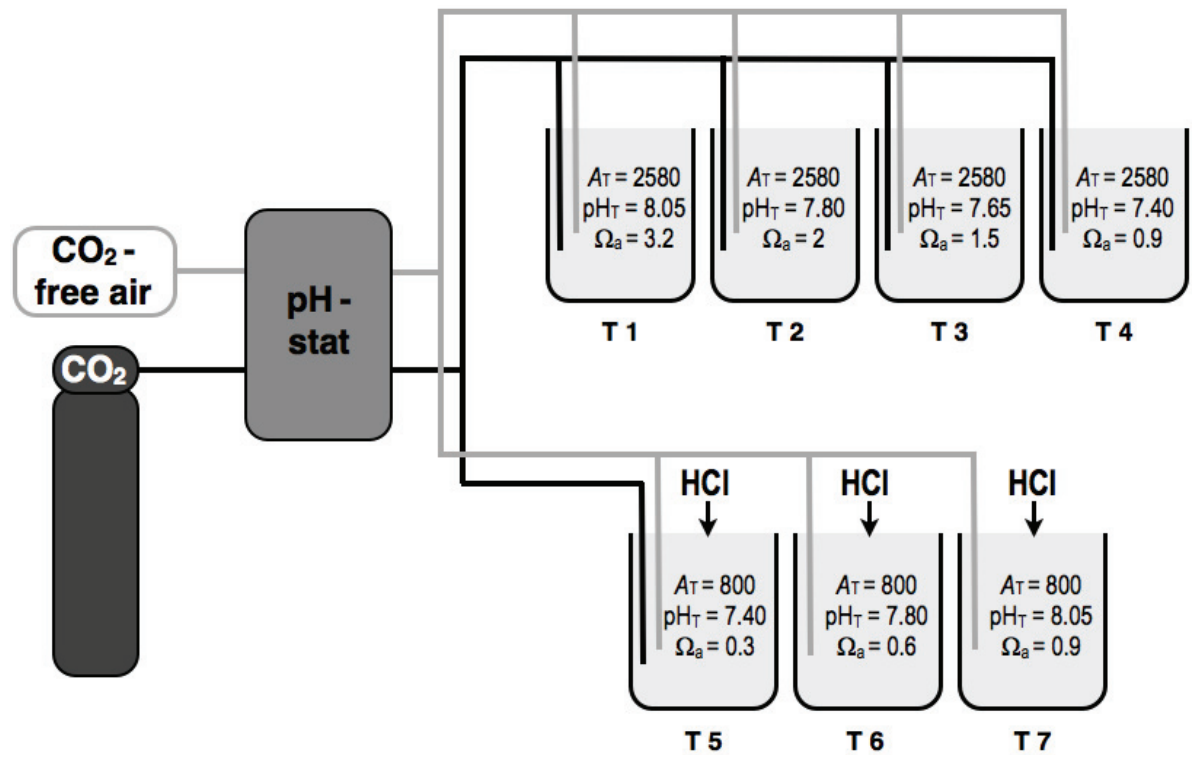

Fig. 1. Experimental set-up used $\left(T=19^{\circ} \mathrm{C}, S=38\right)$. For each treatment the target $A_{\mathrm{T}}$ (total alkalinity in $\mu \mathrm{molkg}^{-1}$ ), $\mathrm{pH}_{\mathrm{T}}$ and $\Omega_{\mathrm{a}}$ (saturation state of the seawater with respect to aragonite) are indicated. $\mathrm{pH}_{\mathrm{T}}$ was controlled by a $\mathrm{pH}$-stat that bubbles pure $\mathrm{CO}_{2}$ and by continuous bubbling of $\mathrm{CO}_{2}$-free air in the beakers. $A_{\mathrm{T}}$ was decreased in $\mathrm{T} 5, \mathrm{~T} 6$ and $\mathrm{T} 7 \mathrm{by} \mathrm{HCl}$ addition (see text for details).

\section{Effect of the carbonate chemistry on a pteropod}

S. Comeau et al.

\section{Title Page}

Abstract Introduction

Conclusions References

Tables

Figures

14 $>$ I

4

Back

Close

\section{Full Screen / Esc}

Printer-friendly Version

Interactive Discussion 

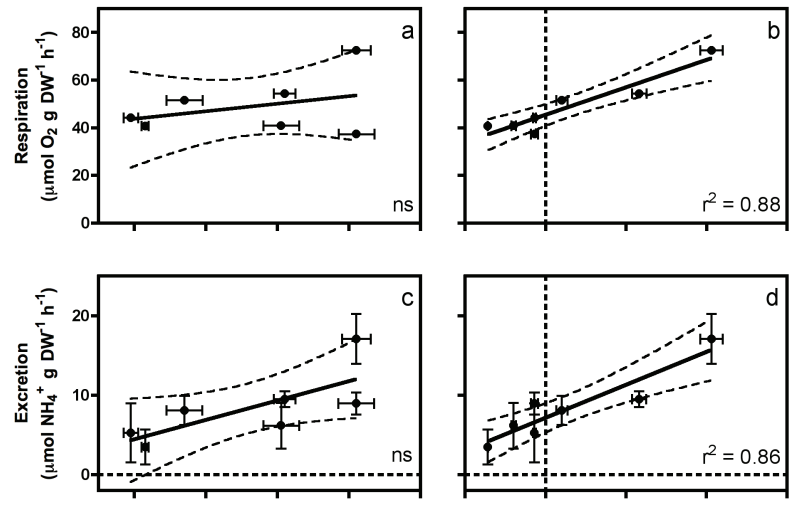

BGD

9, 6169-6189, 2012

\section{Effect of the carbonate chemistry on a pteropod}

S. Comeau et al.
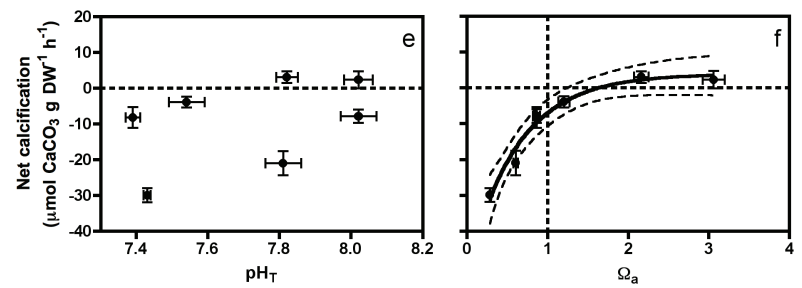

Title Page

Abstract

Introduction

Conclusions

References

Tables

Figures

14

$>$ I

4

Fig. 2. Respiration (a,b), excretion (c,d) and net calcification rates $(\mathbf{e}, \mathbf{f})$ of $C$. acicula as a function of $\mathrm{pH}_{\mathrm{T}}$ and of the aragonite saturation state $\left(\Omega_{\mathrm{a}}\right)$. The dashed lines represent the $95 \%$ confidence interval of the linear and non-linear regressions, ns meaning not statistically significant $(p>0.05)$. The error bars are SD, except in panels $\mathbf{a}$ and $\mathbf{b}$ (respiration rates) where the vertical error bars (not visible) represent the standard error of the linear fitted model (see Materials and Methods).

\section{Full Screen / Esc}

Printer-friendly Version

Interactive Discussion

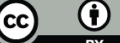




\section{BGD}

9, 6169-6189, 2012

\section{Effect of the carbonate chemistry on a pteropod}
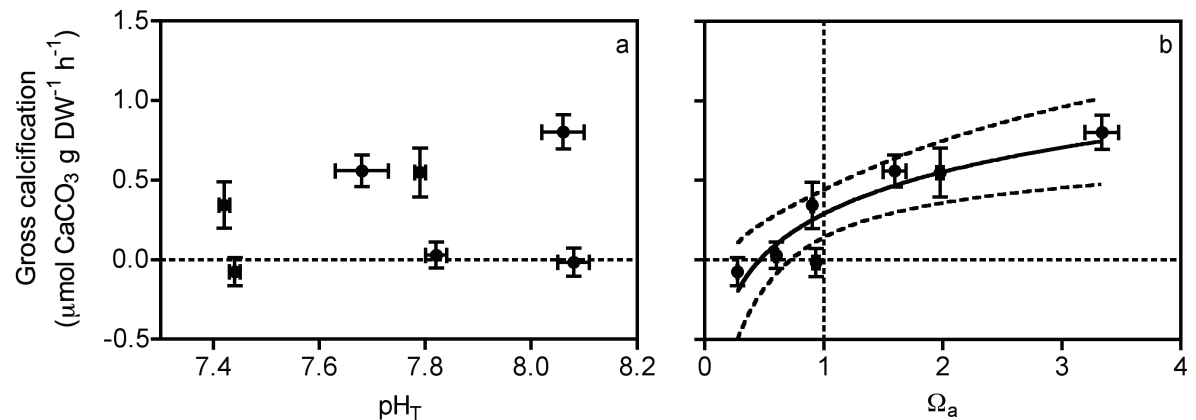

Fig. 3. Rate of gross calcification based on ${ }^{45} \mathrm{Ca}$ uptake as a function of $\mathrm{pH}_{\mathrm{T}}$ (a) and the aragonite saturation state $\left(\Omega_{\mathrm{a}}\right.$; (b). The dashed lines represent the $95 \%$ confident interval of the non-linear regression, ns meaning not statistically significant $(p>0.05)$. The error bars are SD.

\section{S. Comeau et al.}

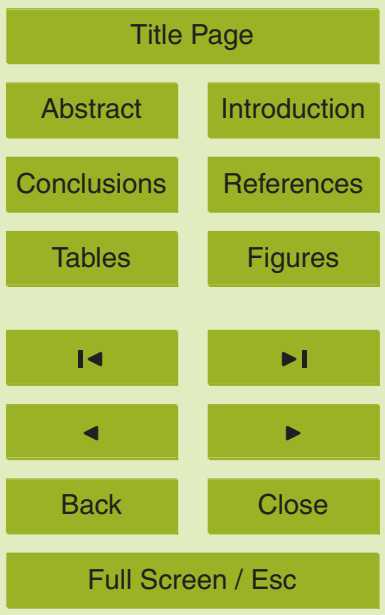

Printer-friendly Version

Interactive Discussion 